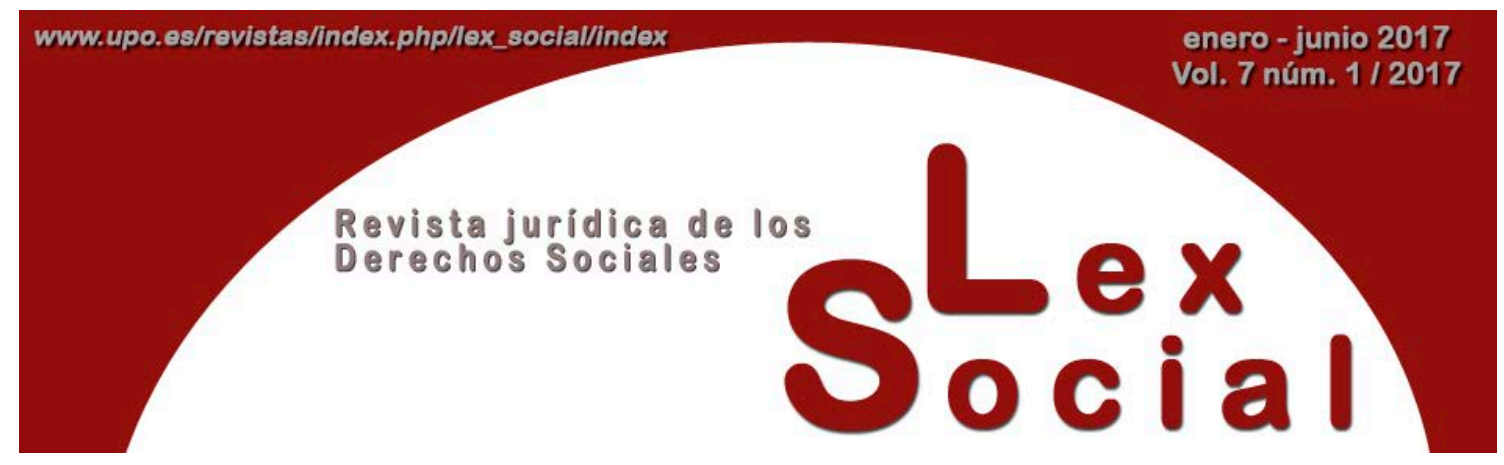

\title{
COMPARING FUNDAMENTAL SOCIAL RIGHTS IN THE EUROPEAN AND THE INDIAN UNION
}

\section{COMPARAISON DES DROITS SOCIAUX DANS L'UE ET L'UNION INDIENNE}

\begin{abstract}
The social part of market economy is played by social rights interacting with economic and cultural rights. The gap between the great ideals of social justice and a reality of these "weak rights" protected by weakened states is the subject of a worldwide political and legal drama. European and Indian social rights discourses are linked by international human rights law and common traditions of social constitutionalism, but face extremely different realities. Starting with a comparative contextual analysis, the paper outlines the concept and common "spirit" of social rights as a thin, neither neoliberal nor socialist synthesis and hybridisation of national constitutional and international law. Comparing the European and the SAARC Social Charter, changing welfare systems can learn from each other. The new EU social rights pillar has to preserve federal diversity.
\end{abstract}


The Indian invention of a right to sleep could include a right to have dreams and the hope that social rights will not remain sleeping rights.

KEY WORDS: international law, indian social rights, European Social Charter, human rights.

\section{RESUME}

La partie sociale de l'économie de marché est intégrée par les droits sociaux qui interagissent avec les droits économiques et culturels. La distance entre les grands idéals de justice sociale et la réalité de ces droits faibles protégés par États faibles est l'objet d'un débat international, politique et légal. Les droits sociaux européens et indiens sont liés par le droit international des droits humains et par les traditions communes du constitutionalisme social, mais ils doivent faire face aux réalités vraiment différentes. Á partir de une analyse comparée et contextuelle, l'article souligne le concept et l'esprit commun des droits sociaux qui sont une subtile, ni néolibérale ni socialiste, synthèse et hybridation de droit constitutionnel national et droit international. Comparer les chartes sociales européen, SAARC, systèmes d`aide sociale changeants ont la possibilité de apprendre l'un de l'autre. Le nouveau pillier européen des droits sociaux doit préserver la diversité fédérale. La création indienne du droit à dormir pourrait inclure un droit à rêver et l'espoir que les droits sociaux ne resteront pas des droits dormants.

MOTS-CLES: droit international, droits sociaux indiens, Charte Social Européenne, droits de l'homme

\section{SUMARIO}

\section{Starting insights}

2. Comparative contextual analysis

3. The spirit and concept of social rights in European constitutional and legal traditions

4. The state of Fundamental Social Rights in the European Union: more virtual than real progress?

5. The European Social Charter compared to the SAARC Social Charter

6. Learning opportunities 


\section{Starting insights.}

From a legal point of view, the social part of what European call the "social market economy" is played by social rights that interact both with economic and cultural rights. An ongoing worldwide political and legal drama is facing the gaps between yellow ideals of happiness and a grey reality of "weak rights" granted by weakened states under the pressure of globalization. The 2030 Agenda for Sustainable Development (2030 Agenda) and at least the first 12 of the 17 Sustainable Developments Goals (SDGs) adopted at the UN Summit in September 2015 (A/RES/70/1) recognize that fundamental social rights are still under construction and often reduced to goals to be scored. The European and the Indian social rights dramas focus different economic and cultural realities of more and less developing countries, but they are connected through international human rights law and common traditions of what we can call social elements of constitutionalism or "social constitutionalism" tout court.

If we look at the European Union (EU) law, Christian Joerges deconstruction of the concept of "social market economy" (2004) was sceptical on whether a judicial activism of fundamental social rights and the open method of coordination of social policies could "bridge the gap between the economic and the social constitution of Europe". 1 The final Lisbon treaty has neither promised a "Social Union", nor prescribed an "Unsocial Union", but it has strengthened social rights through the Charter of fundamental rights and it has enlarged the social policy-competencies of the Union, prospecting in its preamble "economic and social progress" based on solidarity between the peoples and on the attachment of all EU states to fundamental social rights. For the purpose of a "highly competitive social market economy, aiming at full employment and social progress", the EU shall "combat social exclusion and discrimination", promote social justice and protection, equality between woman and men, solidarity between generations and protection of the rights of the child" and "economic, social and territorial cohesion and solidarity among Member states” (art. 3 (2) TEU). The paper aims to demonstrate that these commitments are not just slogans of good will and soft law, but a further little step in a long path of progressive realisation of social human rights that limit and legitimise the social market economy. Notwithstanding the new social rights pillar strategy of Mr. Juncker, these ideals of a European social constitutionalism are still associated mostly to the national state, a genuine product of common European history that is facing with diverging performances new challenges of financial crisis and migration and even moments of crisis of the European Union itself.

\footnotetext{
${ }^{1}$ Joerges, C. and F. Rödl. 2004. "Social market economy” as Europe’s Social model ? EUI Papers 8, www.iue.it.
} 
If we look at the Indian Union law, Mahendra Pal Singh's (2015) comparative perspective on socio-economic rights depicts an even bigger gap. On the one hand, a written constitution recognizes social rights primarily as directive principles of State Policy (art. 39 c): "that the operation of the economic system does not result in the concentration of wealth and means of production to the common detriment") and, on the other hand, social reality has one of the worst records in wealth equality and socioeconomic indicators, even if compared to the other BRICS that share all specific social rights traditions. ${ }^{2}$ The necessity to bridge the gap allowed a limited judicial activism based on public social interest litigation and on a reinterpretation of the general rights to life and personal liberty combined with human dignity that supported a sort of hard core of the social rights defined by art. 24 and 25 of the Universal Declaration of Human Rights (UDHR), specially food, education, housing, health care, livelihood. Nevertheless, the ideals of this form of social constitutionalism seem to be not only under the stress of what Upendra Baxi calls a "structural adjustment program" directed against Indian judicial activism. ${ }^{3}$ While the "NHRC-India Submission to the UN Human Rights Council for India’s Second Universal Periodic Review” (2012) criticised the outcomes of governmental "flagship"-initiatives, ${ }^{4}$ the working group recognized significant efforts in the sphere of social and economic advancement and the achievement of the Millennium development goals, but recommended to sign the Optional protocol to the International Covenant of Economic, Social and Cultural Rights (ICESCR). ${ }^{5}$

In order to promote a new Indo-European dialogue, the paper offers first a comparative contextual analysis of the argument looking at the common geo-history, the different institutional frameworks, political cultures, legal systems and economic performances and the relevant international relations (2). The next step will be an attempt to outline a common "spirit" and concept of social rights in Europe as a thin, neither neoliberal nor socialist synthesis and as a hybridisation of national legal and constitutional traditions and international law that could be compared with the Indian case (3). The paper looks in a further step at the state of social rights within the European Union, specially the European Social Model and the ways of Europeanization of social policies and their interaction with changing European welfare state systems (4). In the following step the European Social Charter will be compared to the SAARC Social Charter and further opportunities of social rights protection will be explored (5). The final question with only partial answer is what the European and the Indian Union could learn from each others' social rights protection experiences (6).

\footnotetext{
2 Singh, M.P. 2015. 'Socio-Economic Rights in India: A Comparative Perspective', Jahrbuch des öffentlichen Rechts, [Yearbook of Public Law, Germany] 643-678.

${ }_{3}^{3}$ Baxi, U. 2014. Towards a Structural Adjustment of Judicial Activism? Paper presented at the conference: Diversity and the Courts: Judicial Pluralism in India, Turin 18-19 September 2014.

${ }^{4} \mathrm{http}: / /$ hhrc.nic.in/Documents/Reports/UPR-Final\%20Report.pdf.

${ }^{5}$ http://daccess-dds-ny.un.org/doc/UNDOC/GEN/G12/151/08/PDF/G1215108.pdf?OpenElement
} 


\section{Comparative contextual analysis}

Any transcontinental dialogue and comparison has to practice precaution, being aware of the asymmetries of knowledge and the dangers of romantic exoticism, magisterial arrogance or curatorial particularism. ${ }^{6}$ The European Union and the Indian Union have prima facie extremely different and far distant social rights discourses. In order to measure and prospect the circulation of legal ideas and models of social rights between both Unions, one should bear in mind various relevant contexts: the common history matters (1), different institutional frameworks (2), different political cultures of democracy (3), different legal cultures (4) and different economical performances (5), but common international relations (6).

(1) The history of Eurasian migrations and Indo-European languages since the so called axial age and along the Silk road has framed a common Eurasian cultural heritage of legal myths and ideas, including the sacredness of “jeu(o)s" (jus) ${ }^{7}$ as well as the inventions of empires and the rule of law (Rajadharma vs. nomos basileus). The memory of this common legal heritage has been divided by occidentalism/orientalism and partially cancelled by experiences of colonialism, but it could still support modern cosmopolitanism as well as minority rights discourses against ongoing clashes of civilizations. The lost memory of the Indian roots of the Sinti minority in Europe is just one example, the lost memory of the European roots of the concept of nationhood another. Looking at this common history, social rights are first of all grounded on the ancient duties to take care and give hospitality to the poor, the ill and the stranger, duties that have been ruled and institutionalized prior to the Christian caritas and Islamic zadak in Hindu Dāna and Hebrew tzedakah. Already the Babylonian king Hamurabi codified its laws for the purpose "that the strong might not injure the weak, in order to protect the widows and orphans". ${ }^{8}$ The ancient rule of law could have been a rule of social law.

(2) The different forms of federalism in both Unions matter for social rights protection. Meanwhile the Indian Union is a sovereign national mega-state, based on a postcolonial constitution with federalism and social directives, the European Union is a treaty based on a supranational federation (or confederacy) of pre-existing nation-states with different constitutional cultures and welfare systems and a principle of solidarity tempered by subsidiarity. The Indian Union is centralized, but moving towards more federalism, notwithstanding strong experiences of partition and secessionism. ${ }^{9}$ The EU is less centralized and governed by an executive federalism under a perceived German hegemony, shocked by the BREXIT referendum and an increasing north/south divide,

\footnotetext{
${ }^{6}$ Sen, A. 2005. The Argumentative Indian, London: Penguin, 139ff.

7 Benveniste, E. 1973. Indoeuropean Language and Society, Nondon: Faber, 379ff; critical Thiruvengadam, A. 2012. Excavating Constitutional Antecedents in Asia: An Essay on the Potential and Perils, 88 Chi-Kent. L. Rev. 45. Available at: http://scholarship.kentlaw.iit.edu/cklawreview/vol88/iss1/5

${ }^{8}$ http://avalon.law.yale.edu/ancient/hamframe.asp.

9 Singh, M.P. 2005. 'The Constitution of India: Symbol of Unity in Diversity', 53 Jahrbuch des öffentlichen Rechts der Gegenwart, 649-686.
} 
but it is still facing further demands of accession and expectations of social federalism. ${ }^{10}$ Sovereignty and federalism matter both for the performance and effectivity of social rights, because federalism could stimulate solidarity among communities. Federal frameworks don't necessarily enhance social homogeneity and strong solidarity among territories, but they can promote a sufficient degree of social cohesion and support social rights related services at local and regional level, but the performance of social rights under federalism has not yet been measured with universally recognized social rights indicators. The EU might become a model for a South Asian Economic Union, but federal solidarity among rich nations could be less difficult than among countries with more poverty.

(3) Even democracy and political culture matter for the protection of social rights. The imperfections of democracy could be a factor and/or a consequence of the weakness of social rights and state directives, especially if associated to a concept of capabilities. ${ }^{11}$ India is considered the "largest democracy of the world" with a great pluralism of languages, religions and political parties, but even still high illiteracy and some troubling "clashes within". ${ }^{12}$ On the other hand, the EU is developing a proper model of "transnational democracy"13 and their post-authoritarian democracies are facing tendencies of post-democracy. On the one hand, the Indian concept of democracy has still the purpose of a "socialist" and "secular" form of state, on the other hand, democracy in the EU aims to be grounded on values of a society where "pluralism, nondiscrimination, tolerance, justice, solidarity and equality between women and men prevail” (art. 2 TEU). Both unions converge on new common ideals of "inclusive democracy” and democratic "responsiveness", but face new realities of plutocracy, technocracy, videocracy ecc.

(4) Differences in social rights protection can be grounded in different rule of law conceptions. Social rights need specific legislation and administration and can find special judges for labour, welfare and administrative justice. The Indian law has a common law culture, integrated by oriental sources of Hindu law and other sources, meanwhile the EU law aims to offer a European synthesis of different national legal cultures, being supported by a common historical basis of Roman law. Common law traditions could be perceived as more liberal or market friendly than social rights centred, meanwhile civil law traditions can transform the "rule of law" in a "rule of social law" (sozialer Rechtsstaat). The judicial review of legislation being practised in both unions and most EU member states, socio-economic rights can find more weak forms of political and administrative protection, for example in more realism oriented Scandinavian legal cultures.

\footnotetext{
${ }^{10}$ See Dann, P. 2011. Federal Democracy in India and the European Union: Towards Transcontinental Comparison of Constitutional Law, Verfassung und Recht in Übersee, 160-176.

${ }^{11}$ Sen, A. 1999. Development as Freedom. New York: Knopf; Nussbaum, M. 2003. 'Capabilities as Fundamental Entitlements: Sen and Social Justice'. 9 Feminist Economics 33ff.

12 Nussbaum, M. 2007. The Clash Within, Harvard University Press.

${ }^{13}$ Prominent Habermas, J. 2011. ,Die Krise der Europäischen Union im Lichte der Konstitutionalisierung des Völkerrechts‘, in: id., Zur Verfassung Europas, Berlin: Suhrkamp, 39ff.
} 
(5) The Indian economy is still fast growing with lower-middle incomes, the locomotive of BRICS, meanwhile the high income countries of the EU, India's largest trade and investment partner, suffer more the global economic slowdown and sovereign debt crisis and the Euro-group countries have more unemployment than other EU-states. Both Unions are members of the WTO, but the EU is only a cooperation partner, not a member of World Bank and World Monetary Fund. The OECD recommended India to improve the macroeconomic framework, to raise employment through a more flexible labor law, to increase female economic participation and to improve health outcomes for all. ${ }^{14}$ No specific recommendations to EU have been made, but the troika's recommendations to Greece and other countries have been found incompatible with several social rights guarantees by the European Committee of Social Rights. ${ }^{15}$ Meanwhile in India economic growth seems to favor poverty reduction, in the Eurogroup austerity policies are suspected to harm the social rights.

(6) EU-India relations are relations among soft powers with voting diasporas. ${ }^{16}$ The European Union was created in the context of larger organisations of the such as the Council of Europe (CoE), NATO (1949) and OECD (1961) and has a special status in ILO, WHO and UNESCO, the Indian Union is a regional power in the Asia-Pacific region, part of the Commonwealth and of the South Asian Association for Regional Cooperation (SAARC), with neighbour states that have more constitutional social rights provisions than other Asian countries. Inspired by a common interest in a new bridging multilateral order based on peace and at least a minimum of global social justice, both are committed to development cooperation and have since 2004 a strategic partnership with an annual "local" human rights dialogue. Main areas of EU concern include poverty, caste discrimination (Dalits), violence against women, children's rights, rights of indigenous people (Adivasis) and poor prison conditions. ${ }^{17}$ Negotiations of a "broadbased bilateral trade and investment agreement” have been stopped when India rejected clauses for the protection of labour rights and environmental sustainability. ${ }^{18}$

\footnotetext{
${ }^{14}$ OECD Economic Surveys: India 2014, DOI:10.1787/eco_surveys-ind-2014-en.

${ }^{15}$ European Committee of Social Rights, Panhellenic Federation of Pensioners of the Public Electricity Corporation v Greece (2012), Complaint No. 79/2012.

16 Mahotra, S. 2015. EU-India Relations: A Soft Power Approach , http://www.eias.org/wpcontent/uploads/2016/02/EU-Asia-at-a-glance-Malhotra-EU-India-Relations-A-Soft-Power-Approach$\frac{2015 . p d f}{17}$ (dec. 2015).
}

http://www.europarl.europa.eu/RegData/etudes/ATAG/2015/551312/EPRS ATA(2015)551312 EN.pdf and

http://www.europarl.europa.eu/RegData/etudes/STUD/2015/534987/EXPO_STU(2015)534987_EN.pdf:

"The Indian human rights situation could improve mainly through the above-mentioned domestic debates and active participation of civil society (discussed separately). Condemnations and resolutions by the European Parliament or other EU institutions may not prove particularly helpful and could even adversely affect bilateral ties. Since it is mandatory for the EU to include human rights clauses in trade agreements, the best engagement strategy for both would be to upgrade and expand dialogue, which would also provide opportunities to discuss and remove mutual misperceptions."

18 Zwagemakers, F. 2012. The EU's Conditionality Policy: A New Strategy to Achieve Compliance, Milano: Giuffré 12 http://www.iai.it/sites/default/files/iaiwp1203.pdf 
Meanwhile most EU development projects support social rights, the EU-India Agenda for Action-2020 (2016) gives only a mandate to "explore possibilities within G20 to enhance collaboration to promote decent work, productive employment, social protection and occupational safety and health and fostering sustainable global supply and value chains”.

\section{The spirit and concept of social rights in European constitutional and legal traditions}

The common tradition of social rights protection in Europe has been today at least partially "constitutionalised" through sources of constitutional law as well as through sources of regional international human rights law. The European tradition has a prechristian matrix in the concepts of "cura" and "se-curitas" that were grounded in stoic ideals of dignity. ${ }^{19}$ The transformation of the religious and political duties of solidarity first in pre-modern institutions of ecclesiastical and civic social assistance and later in contemporary secular social rights was promoted mainly by cultural revolutions. Subjective rights were invented at the same time when medieval canonical law recognized that "by natural law all things are common, which means in times of necessity they must be shared with those who need them". ${ }^{20}$ Italian Renaissance developed a dignity concept open for human creativity and opposed to ascetic concepts of miseria hominis, but only the modern constitutions outlined liberty, equality and fraternity as leading principles in human and citizen's rights.

Meanwhile the US-declaration of independence declared a right to the "pursuit of happiness", the French declaration invoked in its preamble the welfare of all (bonheur de tous) and added the famous definition of constitutionalism whereby a society that doesn't divide the powers and "ensure" (assurer) the rights has no constitution at all. The duty to ensure the rights implied not a legal right to security, but a right of access to justice and to military or civil service.

Sieyes' preliminaries of the Constitution recognized furthermore a right of all citizens to share the benefits (bienfaits) of their "social union". Citizens that by force of a malheur

\footnotetext{
${ }^{19}$ Cicero, T., De officiis, I, 69 : "Vacandum autem omni est animi perturbatione, cum cupiditate et metu tum etiam aegritudine et voluptate nimia et iracundia, ut tranquillitas animi et securitas adsit, quae affert cum constantiam tum etiam dignitatem." “Again, we must keep ourselves free from every disturbing emotion, not only from desire and fear, but also from excessive pain and pleasure, and from anger, so that we may enjoy that calm of soul and freedom from care which bring both (moral) stability and dignity (of character).” See Zwierlein, C. 2015. ,Se-curare, sine cura, se-curitas, assecuratio: Innovationen der Sicherheitsproduktion in der Renaissance‘, in: Melville, G. and G. Vogt-Spira, M. Breitenstein (eds.), Sorge, Köln: Böhlau, 109.

${ }^{20}$ Uguccione de Pisa quoted by Van Beuren, G. 2013. 'Socio-economic Rights and a Bill of Rights - an overlooked British traditio’, Public Law, 822. The Latin version is quoted by Marchettoni, L. 2008. Ockham e l'origine dei diritti soggettivi', Quaderni fiorentini per la storia del pensiero giuridico moderno, 37. N'evertheless canonical law allowed slavery over non Christians. When the British Emancipation Act of 1833 abolished slavery and slave trade for the British Empire, exceptions were still made for the possessions of the East India Company.
} 
were unable to satisfy their needs should be ensured the "just rights to get help (secours) from their con-citizens". Human beings would need a good public education and instruction system and the Nation would need an active control over its relations with over peoples. Nevertheless the declaration should not list all the values of a good constitution, being sufficient to establish a right of citizens to all action the state can take on their benefit. ${ }^{21}$

Under the Jacobin Constitution of 1793 that declared directive principles on social aid and public education (art. 22, 23), slavery was abolished, but Napoleon revoked that decision and the declaration of 1815 granted only free primary school (art. 11). Karl Marx observed ${ }^{22}$ that the preamble of the constitution of 1848 transformed vindicated rights to education, labour and to "support of the orphan, the infirm and the aged" into directive principles of the Second Republic (art. 8), preceded by a duty of the individual "to ensure themselves through work the means of existence and through foresightedness ("prévoyance") the resources for the future; they shall concur to the common wellbeing by helping each other like brothers and to the general order by observing moral rules and written laws that reign the society, the family and the individual." The liberal model of social state was therefore declined any subjective public social right. ${ }^{23}$

During the eighteenth century, the liberal reluctance to social rights prevailed all over Europe. Social rights became popular and constitutional commitments only through the revolutions of last century, in Latin America through the Mexican Constitution of 1917 and in Europe after the trauma of the first world war through the Constitutions of Weimar in 1919 and of Stalin in 1937. The fundamental rights and duties provisions of the Weimar Constitution translated the general principles of social protection provided for the new International Labour Organisation by the almost hated treaty of Versailles in guarantees of a "social existence respecting human dignity for all” (menschenwürdiges Dasein). ${ }^{24}$ As an alternative, corporatist and fascist regimes strengthened fundamental social duties, socialist regimes tried to realize social rights without markets.

\footnotetext{
${ }^{21}$ Sieyes, E. 1789. Préliminaire de la Constitution, Paris : Baudouin 32-3: « On fait que ceux des citoyens qu'un malheur fort condamne à l'impuissance de pouvoir à leur besoins, ont de justes droits aux secours de leurs Concitoyens, \& c. On sait que rien n’est plus à l'espèce humain, au moral \& au physique, qu'un bon système d'éducation et d'instruction publique \& c. On sait qu'une Nation forme avec les autres peuples des relations d'intérêt qui méritent de sa part une surveillance. Toujours active, \& c. Mais ce n’est pas dans la déclaration qu'on doit trouver la liste de tous les bien qu'une bonne Constitution peut procurer aux peuples. Il suffit ici de dire que les citoyens ont droit à tout ce que l'Etat peut faire en leur faveur. »

${ }^{22}$ Marx, K. 1851. The Constitution of the French Republic Adopted November 4, 1848, Notes to the People No. 7, June 14, 1851 http://marx.libcom.org/works/1851/06/14.htm.

23 See E. Wiederin, E. 2005. 'Sozialstaatlichkeit im Spannungsfeld von Eigenverantwortung und Fürsorge’, 64 Veröffentlichungen der Vereinigung der Deutschen Staatsrechtslehrer (VVDStRL) $61 \mathrm{ff.}$

${ }^{24}$ Art. 427: "First. The guiding principle above enunciated that labour should not be regarded merely as a commodity or article of commerce. Second. The right of association for all lawful purposes by the employed as well as by the employers. Third. The payment to the employed of a wage adequate to maintain a reasonable standard of life as this is understood in their time and country. Fourth. The adoption of an eight hours day or a forty-eight hours week as the standard to be aimed at where it has not already been attained. Fifth. The adoption of a weekly rest of at least twenty-four hours, which should include
} 
A research carried out in 1999 for the EU pointed out that after the end of the second world war social rights have been more and more constitutionalised and protected in different forms and degrees of justiciability. With the exception of the UK - the homeland of common law hasn't a single constitutional texture but a strong tradition of social legislation highlighted by Beveridge's Report of 1942 and echoed by Franklin D. Roosevelt's freedoms "from fear and want" - all European constitutions include at least one social right, even Germany and Austria, where at least mothers or children have social rights (and regional constitutions provide further guarantees). ${ }^{25}$

The constitutional entrenchment of social rights is more advanced in southern than in northern Europe, including specific subjective rights to education, health care, social security, work, rarely housing, but never food or water, sometimes a constitutional declaration of a general human right to "a decent life and to social security" (art. 9 Cyprus) or to "lead a life in keeping with human dignity" (art. 23 Belgium). The rights clauses have been in some cases surrogated, in others integrated by directive principles of social policy (art. 45 Ireland) and fundamental constitutional principles of state action for substantial freedom and equality (art. 3 (2) Italy), for the "personal, economic and cultural wellbeing of the individual" (art. 2 (2) Sweden) or simply for the "sozialer Rechtsstaat" (art. 28 (1) Germany), a rule of law for a social state that allows to protect even positive obligations deriving from classical liberties. ${ }^{26}$

The textual differences are partially compensated by further explicit or implicit general clauses that oblige most EU-countries to make interpretation of laws "in the light" of international law, including existing regional human rights instruments such as the European Social Charter (ESC). Europe has already a common concept of social rights in the Council of Europe $(\mathrm{CoE})$ and EU-law that includes a standard set of rights or directive principles for education, healthcare, social security, specific protection for weak categories (woman, children, elders, disabled) and for a healthy environment. This concept is open for "new social rights" related to development, land, housing, food, water and internet., the doctrines and practices of European Constitutions have framed furthermore a common European constitutional standard on the basis of a core right of a person to get protected in its own "social existence” and various forms of legal

Sunday wherever practicable. Sixth. The abolition of child labour and the imposition of such limitations on the labour of young persons as shall permit the continuation of their education and assure their proper physical development. Seventh. The principle that men and women should receive equal remuneration for work of equal value. Eighth. The standard set by law in each country with respect to the conditions of labour should have due regard to the equitable economic treatment of all workers lawfully resident therein. Ninth. Each State should make provision for a system of inspection in which women should take part, in order to ensure the enforcement of the laws and regulations for the protection of the employed.”

${ }^{25}$ Still sceptical Fabre, C. 2005. 'Social Rights in European Constitutions', in: De Burca, G., B. de Witte and L. Ogertschnig (eds.), Social Rights in Europe, Oxford University Press, 18. In Austria an overlapping reform consensus is acknowledged by Schäffer, H.and R. Klaushofer, 2014. ,Zur Problematik sozialer Grundrechte?, in: Mertens, D. and H. Papier. 2014. Handbuch der Grundrechte in Deutschland und Europa, VI: Österreich, Heidelberg 3d ed., 76ff.

${ }^{26}$ http://www.europarl.europa.eu/workingpapers/soci/pdf/104_en.pdf 
guarantees of social security referred to property, equality or dignity rights or principles. $^{27}$

The degree of constitutional entrenchment of social rights is not necessarily relevant for social expenditure and redistribution, but it is much disputed to what extent the success of the "social state" is conditioned by the force of institutions and the ethnic homogeneity of the national state. One could object that the force of institutions and the perception of homogeneity can be conditioned by religious energies and by the force of the constitution as a whole. Social justice and security are at any case purposes of the European pactum societatis et subjectionis that citizens agree and accept for governments. $^{28}$

A study of the European University Institute of 2010 showed that the Charter of Fundamental Rights of the European Union (CDFEU) of 2000 has strengthened the principle of indivisibility of human rights, a principle that is binding for the Union but does not impose the homologation of the national social rights protection policies and legal cultures. ${ }^{29}$ On the one hand, the EU-law reflects the trend to take them more seriously and to promote both individual and collective complaints of social rights. On the other hand they still rely in different forms and degrees to the specific constitutional identities of the European national democracies. As long as the national systems of social security are regarded, comparative social and political research divides the welfare capitalism in Europe in three areas: the liberal, the conservative-corporatist and the social-democratic one. ${ }^{30}$ The legal comparison presents five models of welfare in the EU-countries in an geographic order of decreasing economic competitiveness:

(1) the Nordic welfare, based on universal citizenship rights with collective responsibility for extensive public services for health, education and job placement, extensive public employment and unemployment insurance managed by trade unions;

(2) the Anglo-Saxon welfare, based on a national health service and residual entitlements of the poor through targeted, needs-based state action with individual responsibility in conditions of equality of opportunities and selfreliance maximising markets, deregulated labour market and decentralized labour relations;

(3) the North-Western version of continental welfare, based on obligatory social insurance for workers and their families (Bismarck) and a subsidiary collective responsibility allocated in families, churches and public corporations;

\footnotetext{
${ }^{27}$ Wiederin, E. 2005. ,Sozialstaatlichkeit ..',53.

${ }^{28}$ Langford, M. 2014. 'Judicial Review in National Courts', in: Riedel, R., G. Giacca, and C. Golay (eds.), Economic, Social, and Cultural Rights in International Law, Oxford University Press, 417ff.

${ }^{29}$ University Paris Ouest Nanterre - European University Institute Social Law Working Group. 2010.

Diversity of Social Rights in Europe(S) Rights of the Poor, Poor Rights Working Paper Series EUI LAW 07.

${ }^{30}$ Esping-Andersen, G. 1990. The Three Worlds of Welfare Capitalism, Cambridge University Press.
} 
(4) the Southern version of the continental model, with a lower public social protection that leaves more responsibility to family assistance and voluntary third sector aid and offers a universal health care and highly differentiated pension schemes with deficits in woman employment and more fragmented trade unions (and political parties);

(5) the Eastern versions of welfare in post-communist States with new market economies that adapted and hybridized the other models under international pressure.

These differences explain why national constitutions in Europe have not been homologated to the international instruments of social rights protection. The national concepts and catalogues of social rights and state directives are more or less thick or thin in consideration of their relation to the other categories of rights, specially civil and political rights, being more or less inspired by ideals of liberalism, conservatorism and socialism and by the national design of welfare.

Nevertheless social rights are a concept of a common European public law that has a common content. Social rights can be defined as a species of the genus "fundamental rights" of a human person because they offer at least a minimum of international and constitutional protection and mandatory legislative implementation. They are no more presumed to be not justiciable, but they can still have weaker forms of review in the international and in the national constitutional order. ${ }^{31}$ Social rights can be distinguished from other fundamental rights by their object, being first of all expectations and claims of positive action. The fulfilment of the duty to protect social rights is generally conditioned by a mandate of legislation and of allocation of financial resources, with general principles that command gradual development over time and prohibit unreasonable regression. The duty bearers of social rights are not exclusively the state and sub- or supranational public bodies under a principle of subsidiarity, being such rights even binding for non-state actors, specially for private powerholders like employers, land- and house-owners or parents. The rights of children and workers to get alimentation and pay are most prominent examples of fundamental social rights grounding private and civil law. Finally, even after the end of the socialist regimes in Europe, social rights are encumbered by social duties (to work, schooling etc.) that concretize the responsibilities of the social rights holder for its own happiness. ${ }^{32}$

If this is the common analytical frame of social rights, the common spirit of their constitutional and international guarantees relies mainly to values and fundamental principles of dignity against misery, of positive freedom and substantial equality (no discrimination and equal opportunities), of solidarity duties, inclusive citizenship and effective access to justice.

\footnotetext{
${ }^{31}$ For the constitutional level see Tushnet, M. 2008. Weak Courts, Strong Rights. Judicial Review and Social Welfare Rights in Comparative Constitutional Law, Princeton University Press, 237ff.

${ }^{32}$ Waldron, J. 2010. Socioeconomic Rights and Theories of Justice, New York University Public Law and Legal Theory Working Papers 245, http://lsr.nellco.org/nyu_plltwp/245
} 
This spirit has been strengthened by the incorporation into the CFREU of most rights of the European Social Charter (ESC) that has been ratified by all EU- and CoE-countries except Switzerland, either in the shorter original (Turin 1961) or in the longer revised version (Strasburg 1996) and was early recognized by the EU-treaties and even by the jurisprudence of the European Convention of Human Rights (ECHR). ${ }^{33}$ Under EU-and CoE-law, social rights can be protected both as subjective rights and objective principles, or just respected as objective principles not to be promoted without political competences. The common spirit is a thin but solid, neither neoliberal nor socialist synthesis and hybridisation of national constitutional and legal traditions and regional international law, a spirit that doesn't bring happiness, but helps to reduce the unhappiness in situations of fear and want.

A recent research made by Jung, Hirschl \& Rosevear (2014) divides still sharply the constitutions of post-communist countries from those of "Western Europe and North America”. Latin America and post-communist constitutions would represent a strong entrenchment of economic and social rights, Western Europe and North America "share a strong norm against ESR entrenchment". ${ }^{34}$ A more politically correct geography should recognize that the spirit of social rights is a fundamental of the constitution of the European welfare states and of the EU, being European constitutionalism more social constitutionalism than the North American one. There are of course strong NorthSouth and West-East divides even within EU and CoE, for example on the question whether social rights of citizens should be stronger than those of other human beings. Nevertheless, the Euro-group is promoting a "Social Rights Pillar" that takes social rights seriously as fundamental rights, with adequate international and constitutional guarantees.

\section{The state of Fundamental Social Rights in the European Union: more virtual than real progress?}

The European Union promoted the above said common spirit of fundamental social rights, but didn't fill up the gap between the ideals of social justice and the reality of social inequalities. The EU is not a "social union”, but it could not survive if it would become an "unsocial union", especially on the actual background of the migration crisis. At any case, the performance of the EU in the field of social rights protection is still controversial and uncertain.

If we look at the CRFEU and at the competences of the Union in the field of social policies, the performance of the duty to "respect" will be presumably higher than the performance of the duties to "protect" and "fulfil”. The EU recognizes the indivisibility

\footnotetext{
${ }^{33}$ Tulkens, F. 2003. 'Les droits sociaux dans la jurisprudence de la nouvelle Cour européenne des droits de l'homme, in: Grewe, C. and F. Benoit-Rohmer (eds.), Les droits sociaux ou la démolition de quelque poncifs, Strasbourg : Presses universitaires, $117 \mathrm{ff}$.

34 Jung, C., R. Hirschl and E. Rosevear. 2014. 'Economic and Social Rights in National Constitutions'. 62 American Journal of Comparative Law, 1043-1098. http://ssrn.com/abstract=2349680
} 
of rights and respects most, but not all social rights, being still significantly excluded the rights to housing and to fair remuneration. The realisation of all social rights, however, can be only to partially promoted at EU-level, being still mainly under the responsibility of the member states and their presumptive democratic governments.

If we look at the history of EU-law, the transnational integration process has produced significant welfare tools such as the European Social Fund (1957), the Social security of migrant workers (Regulation No. 1408/71), the Regional Development Fund (1975), the Committee for social dialiague (1992), the European Employment Strategy (1997), the Common Principles of "Flexicurity (2007) and finally the strategies of Lisbon (2000) and Europe 2020 (2010).

More than half of the Europe 2020 agenda seems to be devoted to social policies and even the other economic objectives can be conceived as social investments:

The Digital Agenda is the EU's strategy to help digital technologies, including the internet, to deliver sustainable economic growth.

The Innovation Union aims to improve conditions and access to finance for research and innovation in Europe, so that innovative ideas can be turned into products and services that create growth and jobs.

Youth on the Move provides support for more than 400000 young people each year to work, train and study abroad.

Resource efficient Europe supports a shift towards a more resource-efficient, lowcarbon economy to achieve sustainable growth.

An Industrial Policy for the Globalisation Era sets out a strategy that aims to boost growth and jobs by maintaining and supporting a strong, diversified and competitive industrial base in Europe offering well-paid jobs while becoming more

resource efficient.

The Agenda for New Skills and Jobs is how the Commission will help the EU reach its employment target: $75 \%$ of the working-age population (20-64 years) in work by 2020 .

The European Platform against Poverty and Social Exclusion is designed to help achieve the EU target of lifting at least 20 million people out of poverty and social exclusion by 2020 .

The balance sheet of the state of social rights shows that the EU is no more just an agency for the coordination of social policies of different welfare systems and a partial harmonization of social legislation, but points on specific flagship missions, for example the European Platform against Poverty and Social Exclusion. The competences regarding "social policy for the aspects defined in this Treaty", "common safety concerns in public health matters, for the aspects defined in this Treaty" or "economic, social and territorial cohesion” (Arts. 4, para. 2, 151 ff., 168, 174 TFEU) have been enlarged. The open method of coordination has strengthened the "coordination of the 
employment policies of the Member States, in particular by defining guidelines for these policies" (Arts. 5, para. 2, 145 ff. TFEU) and the "coordination of Member States social policies" (Arts. 5, para. 2, $151 \mathrm{ff}$. TFEU), or "actions to support, coordinate or supplement the actions of the Member States" regarding "protection and improvement of human health; education, vocational training, youth and sport” (Arts. 6, 165, 168 TFEU).

Other areas of EU-policies and activities such as consumer and environment protection, agriculture or infrastructures developed further specific social rights and principles. All areas of competences can be affected transversally by social rights insofar as the EU "shall aim to eliminate inequalities, and to promote equality, between men and women" (Art. 8 TFEU), "take into account requirements linked to the promotion of a high level of employment, the guarantee of adequate social protection, the fight against social exclusion, and a high level of education, training and protection of human health" (Art. 9 TFEU), "take appropriate action to combat discrimination based on sex, racial or ethnic origin, religion or belief, disability, age or sexual orientation” (Art. 19 TFEU). Last but not least, "given the place occupied by services of general economic interest in the shared values", the EU shall take care that such services operate on the basis of principles and conditions, particularly economic and financial conditions, which enable them to fulfil their missions" (Art. 14 TFEU). From a legal point of view, the EU prospects a "highly competitive social market development, aiming at a full employment and social progress, and a high level of protection and improvement of the quality of the environment" (art. 3 para. 3 TEU), with increased economic and social competences. The Union shall combat social exclusion and discrimination and promote social justice and protection, gender equality as well as solidarity between generations and protection of the rights of the child. The legal design of the EU has been bettered and . Even in the political reality one can observe that EU-action has increased occupational safety and health and has promoted more universal and sustainable social protection systems, inclusive labour markets, a multilevel social dialogue and a quality framework for social services of general interest. ${ }^{35}$ This European social model has therefore been considered highly competitive when compared with social policies in the United States, Latin America, Asia and Africa.

Nevertheless, this social model is still under construction, appears vague and inconsistent and is lacking of political consensus and support. In the context of the ambiguous principle of subsidiarity, a "highly competitive social market economy" sounds still like "Keynes at home and Smith abroad". An ambivalent role has been played even by the European Court of Justice (ECJ). On the one hand, ECJ protected social rights as implications of the freedom to move and of the prohibition of

\footnotetext{
${ }^{35}$ VAughan-WhitehEAD, D. (ed.). 2015, The European Social Model in Crisis: Is Europe losing its soul? Cheltenham: Elgar.
} 
discriminations for citizenship, on the other hand the judges stopped collective action of trade unions colliding with economic freedoms (Viking/Laval). ${ }^{36}$

The popular consensus for a European solidarity is still weak. The veto against the constitutional treaty in Netherlands and France was partially motivated by a fear to lose social protection offered by the Nation which is perceived as an enlarged family. A large scale of political actors and electors still prefer to identify social security with "national" security that should remain in the sole responsibility of the members states. When EU faced the banking and financial crisis, political scientists highlighted the persisting asymmetry between a strong neoliberal expansion of economic freedoms backed by the judges (negative integration) and a weak commitment to social policies and market-correction left to national legislators with a more restricted budget autonomy (positive integration). ${ }^{37}$ The discriminating acronym of PI(I)GS during the sovereign debt crisis and the asymmetric effects of austerity policies marked a further loss of confidence and increasing differences between the European welfare states, with people of northern countries anxious to pay for the debts of the poorer countries of the South.

In the European post-industrial societies, new social risks have been imposed to workers and trade union membership is decreasing all over Europe as a result of the single market. ${ }^{38}$ The European welfare states learnt new forms of recalibration and new perspectives of "social investment" 39 . Social rights are no more a hope for socialism, but not even a horror for neoliberalism, but what is the definite state of social rights in the EU remains a controversial question.

A recent commission staff working document for the consultation on a new "European Pillar of Social Rights" acknowledges that unemployment is decreasing, but the risk of poverty or social exclusion affects 1 of 4 persons. ${ }^{40}$ Europe is under demographic pressure as an ageing continent with more female workers, changing family structures, growing diversity of immigration and rising levels of education. The "fourth industrial revolution" takes place with increased employment and social disparities that may weigh heavily on the performance of the Euro area.

As a matter of fact, the EU represents at global level ca. $7 \%$ of population, $25 \%$ of gross domestic product (GDP) and $50 \%$ of social expenditure of the world. ${ }^{41}$ What we

\footnotetext{
${ }^{36}$ Kingreen, T. 2014. 'Epochen der Europäisierung des Sozialrechts', and Rödl, F. 3014. 'Die dialektische Entwicklung des Sozialen im Prozess der europäischen Integration’, in: Masuch, P. (ed.), Grundlagen und Herausforderungen des Sozialstaats: Denkschrift 60 Jahre Bundessozialgericht, Berlin: E. Schmidt, 318ff. and 539ff.; Hervey T. 2014. 'Re-Judging Social Rights in the European Union', in De Burca, G., C. Kilpatrick, and J. Scott (eds.), Critical Legal Perspectives on Global Governance, Oxford, $346 f f$.

${ }^{37}$ Scharpf, F. 2010. 'The Asymmetry of European Integration. Or why the EU Cannot Be a "Social Market Economy”', Socio-Economic Review, $211 \mathrm{ff.}$

${ }^{38}$ Crouch, C. 2016. Society and Social Change in 21st Century Europe, London: Palgrave.

${ }^{39}$ Hemerijck, A. 2012. Changing Welfare States, Oxford University Press.

${ }^{40}$ Key economic, employment and social trends behind a European Pillar of Social Rights, SWD(2016) 50; COM (2016) 127.

${ }^{41}$ Cavalli,A. and A. Martinelli. 2015. La società europea, Bologna: Mulino, 245.
} 
call the "European Social Model" is made today first of all by a public social expenditure rate ${ }^{42}$ per GOP of $28.6 \%$ of all EU-countries and $29,4 \%$ in the Euro-area with larger differences east/west than north/south (for example France 33,7 \%, Greece $31,6 \%$, Finland 31,2 \%, Italy 29,8 \%, Germany 29,0 \%, UK 28,1\%; Poland 17,7 \%, Latvia 14,4\%). Taking all benefits together at constant prices, the annual growth over the 2008-12 period averaged an estimated $1.7 \%$ in the EU-28. ${ }^{43}$

OECD data ${ }^{44}$ show that in recent years some EU-countries such as Greece, Estonia, Germany, Hungary, Ireland and the United Kingdom have experienced substantial declines in social spending, but in most EU-countries social spending remains at high levels. Only if one includes the private expenditures, United States comes closed even to France, meanwhile public spending in emerging economies is lower than the OECD average of 22\%. In the BRICS, Russia (15,7 \%) and Brazil (14,4\%) leads over China (9,1\%), South Africa (8,8 \%) and India (4,6\% in 2007). Development matters:

\section{Public social expenditure as a percent of GDP in 2012 or last year available}

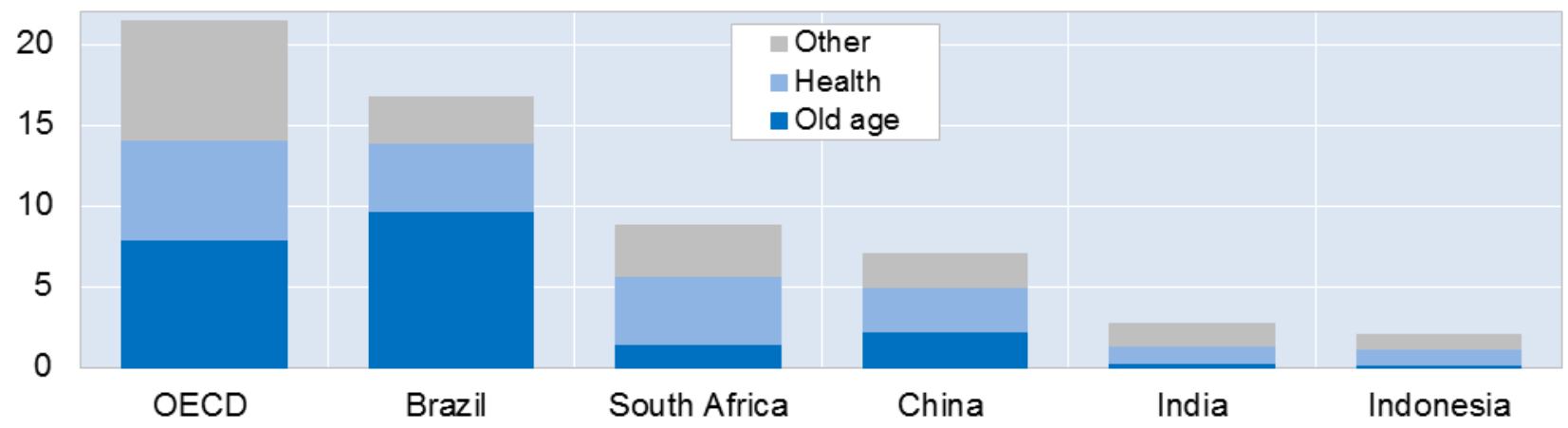

If we ask for the percentages of social expenditure in the EU-budget, no precise answer is given by the institutions. That does not mean that their isn't any expenditure, but the budget is based on various missions and probably any attempt to separate expenditure for economy and for social purposes could be technically hard and politically unwise.

A global benchmarking and benchlearning for the performance of the social objectives is still under way. ${ }^{45} \mathrm{~A}$ comparison EU-India regarding the substantial protection of social rights could be started looking at some macro data:

\footnotetext{
42 Expenditure for old age, sickness/healthcare, disability, family/children, housing, unemployment, survivors (widows and widowers), social exclusion not elsewhere classified.

${ }^{43}$ http://ec.europa.eu/eurostat/tgm/

44 http://www.oecd.org/els/soc/OECD2014-Social-Expenditure-Update-Nov2014-8pages.pdf

45 http://ec.europa.eu/eurostat/statistics-explained/index.php/The EU in the _world__living_conditions. For Germany see Obinger, H. 2014. 'Deutschland im Vergleich zentraler Sozialstaatsindikatoren', in: Masuch P. (ed.), Grundlagen, 47ff.; Scruggs, L. , C. Zimmermann, and C. Jeffords. 2013.
} 
- the $\$ 1.90$ a day poverty headcount ratio (Worldbank) was reduced in India from 31.4\% in 2009 to $21.3 \%$ in 2011, meanwhile monetary poverty and severe material deprivation increased in EU since 2008 with 17\% of Europeans that live on less than $60 \%$ of their country's average household income and $24 \%$ at risk of poverty; ${ }^{46}$

- the unemployment rate in the European Union raised from 7,0 (2008) to 10,8 \% (2013), in the Indian Union from 2,5 (2012) to 4,5 \% (2013); ${ }^{47}$

-the social security in an ageing society is conditioned by the life expectancy at birth, in the EU 80,6 (EU-28 2013) years, in India 69,89 (CIA 2012) - even more increasing,

- the rights of the family are conditioned by the fact that more than three quarters of households in India have four or more persons, compared with one fifth in the EU-28.

\section{The European Social Charter compared to the SAARC Social Charter}

The European Pillar of Social Rights might be strengthened by an accession of the European Union to the European Social Charter (ESC), accession that has been already supported by both the European Parliament and the Parliamentary Assembly of the CoE. ${ }^{48}$ The ESC goes beyond the Nizza Charter (CFREU) insofar as it includes a general right to work, the right to fair remuneration, the right to be protected from poverty and social exclusion, and the right to housing. Today 19 of 28 EU-member states ratified the Revised European Social Charter (RESC) of 1996, 9 states (including Germany and UK) are bound only by the 1961 Charter. Being the signing state free to make a choice of its Charter obligations, it has to added that today only France and Portugal have accepted all obligations. 14 EU member states have accepted the Additional Protocol of 1995 establishing a system of collective complaints to be examined by the European Committee of Social Rights (ECSR). The so called Turin process within the Council of Europe aims to encourage the EU to take the ESC/RESC "into account in the legislative process", to reinforce the dialogue between the ECSR and the Court of Justice (CJEU) and the links to the Fundamental Rights Agency

\footnotetext{
'Implementation of the Human Right to Social Security around the World', in: Lanse, M. (ed.). 2013. The State of Economic and Social Human Rights, Cambridge University Press, $117 \mathrm{ff}$.

46 "Close to $9 \%$ of all Europeans live in severe material deprivation - they do not have the resources to own a washing machine, a car, a telephone, to heat their homes or face unexpected expenses. $10 \%$ of Europeans live in households where no one has a job. There is a wide gap in performance between the welfare systems in different EU countries - the best reduced the risk of poverty by $60 \%$, the least effective by less than $15 \%$ (EU average 35\%)."

${ }^{47}$ http://ec.europa.eu/eurostat/statistics-explained/

${ }^{48}$ Resolution of the European Parliament of 27 February 2014 on the situation of fundamental rights in the European Union (2012) (2013/2078(INI)); Parliamentary Assembly of the Council of Europe, Resolution of 8 December 2014 on the implementation of the Memorandum of Understanding between the Council of Europe and the European Union, at http://www.coe.int/T/DGHL/Monitoring/SocialCharter/Doc_Bruxelles_version_EN_FR_DEF.pdf.
} 
(FRA), to implement "early warning” procedures and, last but not least, to "work towards the proposed accession of the EU to the Charter". 49

Now if we look at the differences between the European and the SAARC Social Charter (SAARCSC), we find first of all the purpose to "ensure an overall and balanced social development of their peoples" (art. 1 SAARCSC) and to "improve their standard of living and their social well-being" (preamble ESC). Being the SAARC committed to "sustained social development” (art. 2) of developing countries (art. 2 sect. 3 ICESR), it aims not only to "facilitate economic and social progress" (preamble RESC) but even "to accelerate economic growth, social progress and cultural development" (preamble SAARCSC).

The SAARCSC furthermore opens with a declaration of "principles, goals and directives” (art. 2) that imply a stronger dimension of ethical responsability, equity, tolerance, universal respect and a human rights education "in the context of inculcating in children intrinsic and attendant sense of duty and set of values directed towards preserving and strengthening the family, community, society and nation".

Human dignity has not only to be "respected" and "protected" (art. 1 CFREU) as a "dignity at work" (art. 26 RESC), it must be "promoted" as well as participatory governance, social justice and solidarity (art. 2 (2) vi SAARCSC) and a person must be enabled to "realize" his or her personal dignity (xiv). A specific vulnerability of "human rights and dignity" is recognized to women and children (art. 6, 7 SAARCSC).

Poverty alleviation is the first topic of the SAARCSC (art. 3), protection against poverty and social exclusion and the last entry in the European Social Charter (art. 30). The success of Meanwhile the Indian report is based on an absolute poverty treshold that is still lower than the Worldbank indicator ${ }^{50}$, the right to social security and the right to social assistance in European countries are construed on the basis of a more relative concept of poverty the minimum social income through two tresholds, a collective one that amounts to $50 \%$ of the country's net median equivalised household income per adult, and an individual that amounts to $40-50 \%$ of the previous earnings of a person (art. 12 RESC as interpreted by the ECSR ${ }^{51}$ ). This minimum social income amounts in Norway to $1.514 €$, in Romania to $88 € /$ month.

The ESC-rights catalogue starts with the right to work and other work-related rights not included in the SAARCSC and only partially guaranteed at constitutional level in India.

\footnotetext{
49 Nicoletti, M. $2014 . \quad$ General Report.

http://www.coe.int/T/DGHL/Monitoring/SocialCharter/TurinConference/Turin-General-Report_EN.pdf.

See Luther, J. 2016. 'Perspectives for an Accession of the European Union to the (Revised) European Social Charter', in: Luther, J. and L. Mola (eds.), Europe's Social Rights under the Turin Process, Napoli: Editoriale Scientifica, 2016, 135ff.

50 See Ministry of Statistics and Programme Implementation, SAARC Social Charter India Country Report 2014

www.Mospi.Gov.In; Datt, G., M. Ravaillon, and R. Murgai, 2016. Growth, Urbanization, and Poverty Reduction in India, Worldbank Poverty and Equity Global Practice Group, WPS 7568.

${ }^{51}$ Mikkola, M. 2016. 'Minimum standards of social income in Europe', in: Luther, J.and L. Mola. 2016. 6ff.
} 
The right to bargain collectively and to collective action in cases of conflicts of interest are not explicitly protected by the Constitution and only half of fundamental ILO Conventions are ratified. ${ }^{52}$

The ESC is based furthermore on concrete undertakings of the member states for the protection of the social rights. Specially the right to health (art. 11 RESC) is protected through concrete duties of prevention, including "the encouragement of individual responsibility in matters of health". The SAARC Charter provides specific goals of "population stabilization" (art. 8) and "drug de-addiction", including a "stabilisation in the growth of population in each country, through voluntary sustainable family planning and contraceptive methods" and prevention of "unsustainable population changes". Even the ESC rights can only partially invoked by migrants.

Finally, different mechanisms are provided for the implementation of the social charters. The SAARCSC distinguishes national implementation the national level through a National Action Plan and a "National Coordination Committee or any appropriate national mechanism as may be decided in each country" and a review through "appropriate SAARC bodies" at the regional level (art. 10). That would neither exclude an agreement for the involvement of the SAARC Arbitration Council, nor the establishment of a specific advisory body similar to the European Committee of Social Rights (ECSR). The independent experts of the ECSR deliver conclusions in reporting procedures and decisions on collective complaints made by organisations of employers and trade unions and NGO's with consultative status. The collective complaints procedure appears as a new form of public interest litigation, but the ECSR is not a judge and the EU has not yet embraced the position of the European parliament for a EU-accession to the revised Charter. If the committee finds that the Charter has not been applied in a satisfactory manner, the Committee of Ministers shall adopt, by a majority of two-thirds of those voting, a recommendation addressed to the Contracting Party. The ECSR-jurisprudence is published, but rarely quoted by courts and academic doctrine.

In conclusion, the SAARCSC is still preferring a state goal approach to the rights approach of the revised ESC, but both instruments recognize that social justice is a global problem with needs of regional protection. They come from a world of divided rights protection regimes, but they could become both more useful for the social rights protection than expected.

\section{Learning opportunities}

\footnotetext{
${ }^{52}$ Not ratified: C087 - Freedom of Association and Protection of the Right to Organise Convention, 1948 (No. 87);

C098 - Right to Organise and Collective Bargaining Convention, 1949 (No. 98); C138 - Minimum Age Convention, 1973 (No. 138); C182 - Worst Forms of Child Labour Convention, 1999 (No. 182); C129 Labour Inspection (Agriculture) Convention, 1969 (No. 129).
} 
The paper moved from the idea that the social part of the highly competitive social market economy has to be played by fundamental social rights that are recognized and protected both at the international level as human rights and at the constitutional level either as constitutional rights or state directives. From a normative point of view, a sustainable social market economy can be reached only through an adequate protection of social rights.

The European and the Indian Union have to bridge serious gaps between yellow ideals of happiness and a grey reality of "weak rights" granted and protected by weakened states under the pressure of globalization. Both Unions focus different economic and cultural realities of more and less developing countries, but are connected through general international human rights law and common traditions of social constitutionalism. Their human rights dialogue needs a postcolonial approach. Comparatists must be aware of socio-cultural differences and asymmetries in knowledge and help institutional operators to learn from each other.

Starting from a comparative contextual analysis, the paper remembers first the common Eurasian heritage not only of empires but even of a "rule of social law". Even the different forms of federalism matter for social rights protection, especially for federal solidarity and for recalibration of welfare systems. The supranational federalism of the EU might become a model for a South Asian Economic Union, but solidarity among rich nations could be less difficult than among countries with more poverty. The EU is considered to be less democratic than the biggest democracy of the world, but the imperfections of all democracies could be both a cause for and a consequence of the weakness of social rights. The different legal cultures could furthermore explain why social rights find less constitutional entrenchment in common law countries than in civil law countries. Even the economic differences are relevant: growth matters for the dimensions of poverty and financial crisis for the sustainability of social rights systems. Finally, the missing India-EU FTA is not hindering an ongoing the human rights dialogue that could even help to focus social rights. Both soft-powers could have common interests in global social justice.

The second chapter shows that there is a common "spirit" and concept of social rights in Europe as a thin, neither neoliberal nor socialist synthesis and as a hybridisation of national legal and constitutional traditions and international law discourses. The constitutional history of social rights teaches that US and Europe do not share a strong norm against ESR entrenchment in constitutions. Notwithstanding German scepticism, all European constitutions include at least one social right and all EU-countries ratified the original and most (except UK and Germany) the revised ESC.

Social rights are no more presumed to be not justiciable ethics, but they can still have weaker forms of review in the international and national constitutional order. They claim for positive state action, but their realisation is generally conditioned by a mandate for legislation and allocation of financial resources with a principle of gradual development over time and a prohibition of unreasonable regression. The duty bearers 
of social rights are not exclusively the state and sub- or supranational public bodies. Social rights imply social duties that concretize even the responsibility of the social rights holder for its own happiness. This concept relies to values and fundamental principles of dignity against misery, positive freedom, substantial equality, solidarity, inclusive citizenship and access to justice which can be construed as universal values.

The third chapter shows that the state of social fundamental rights in the EU is controversial. Aspects of progress are the growing competences and actions, even in the agenda Europe 2020, that move beyond the coordination of welfare systems by focussing social investments. Aspects of regression are increasing inequalities and poverty risks in the North/South and West/East divide. The judges play an ambiguous role in the defence of social rights, the social expenditure rate of the EU is still unavailable and the social rights pillar of the monetary and economic Union is still under construction.

The fourth chapter showed some significant differences between the European Social Charter and the SAARC Social Charter. Both instruments reflect still ideas of a special status of social rights as rights in need of collective protection and state goals, but develop different regional solutions for the common problem of global social justice. The Europeans could learn about action plans for poverty reduction, the SAARClawyers from ESRC “jurisprudence”.

In conclusion, both the European and the Indian Union can learn a lot from each other and from themselves, looking at their social rights discourses as sources of virtue. Europe's social rights discourse teaches a right to hope and a duty to of politicians to promote intelligent social investments. The Indian social rights teach a duty to patience and a right to sleep that implies not only substantial health and working force recreation, but even a right to dream some progress in the realisation of social rights. ${ }^{53}$

\footnotetext{
${ }^{53}$ SC India, Re-Ramlila Maidan Incident Dt ... vs Home Secretary And Ors on 23 February, 2012.
} 